\title{
Horticultural Crop Sales and Participation in Rural Farmed Markets
}

\section{D.T. Lindgren}

Additional index words. participants, Nebraska

Summary. Thirteen farmers' markets have been established in west-central Nebraska with varying degrees of success. Sales and seller participation in the active markets have varied from year to year. Farmers' markets in small communities, as well as in larger metropolitan areas, can be successful.

University of Nebraska West Central Research and Extension Center/Horticulture, Route 4, Box 46A, North Platte, NE 69101. 
$\mathrm{T}$ here has been a renewed interest in the past 10 to 15 years in using farmers' markets for direct-marketing of agricultural products. It is a marketing method that is appealing to many growers as well as many consumers. Much of the information available about farmers' markets comes from markets located in relatively highly populated areas, from surveys conducted for only 1 year, or from surveys of buyers at farmers' markets (Capstick, 1982; Courter et al., 1980; Steinberg, 1986). Information on sales and seller participation at smaller farmers' markets over several years would be useful for determining the potential economic value and feasibility of establishing markets in communities with lower populations.

Thirteen farmers' markets have been started in rural communities in central Nebraska since 1977. Sales information was collected annually from these markets. This information included the number of market days, number of sellers, and reported sales (when available) for each year, of operation from 1977 through 1989 (Table1). Six of the 13 markets are still active. The seven markets that are no longer active existed for an average of 1.7 years, and averaged 10.4 market days per season, 4.1 sellers per day, and 10 different sellers per season. The markets still active through 1989 operated for an average of 11 years, and averaged 11.8 market days per season, 8.1 sellers per day, and 23.1 different sellers per season. Sales data, which were not available for all markets, can be expressed as total sales or can be averaged on a per-seller/season or perseller/day basis.

The North Platte farmers' market has been the most active of all these markets (Tables 2 and 3) and may help to explain the relationship between participation and sales. There was a general increase in total sales and average sales per seller per day at the North Platte market from 1977 to 1987 , and a decrease in 1988 and 1989 (Table 2). The largest total reported seasonal sales for an individual seller at the market varied from a low of $\$ 590$ in 1977 to a high of $\$ 4700$ in 1986 and 1987. The highest 1-day sales by a single seller was $\$ 517$ in 1986 . Seller participation varied from year to year (Table 3).

The success of small farmers' markets varied from community to community in west-central Nebraska. It is difficult to draw conclusions as to why some markets went out of operation based on a comparison of data collected from the active and nonactive markets. However, the active markets averaged about twice as many sellers per day and twice the number of different sellers per season as the nonactive markets.

From discussions with county cooperative extension personnel in the communities involved in these markets, it was observed that markets that draw growers from greater distances and more counties, such as the North Platte market (Table 3), have a more uniform supply of produce, leading to a more stable, balanced, and active market. Farmers' markets that did not remain active generally 1) lacked a uniform and adequate supply of produce, 2) lacked good leadership to promote and operate the market, and 3) lacked cooperation among growers in organizing their marketing activities.

The successful markets promoted themselves through advertising and good public relations and made changes in market operations as needed. These changes include what is allowed to be sold, the time and day of market operation(s), and the fees charged to sellers.

Year-to-year fluctuations in sales are influenced greatly by seller participation and growing conditions. There was a yearly increase in total sales at the North Platte farmers' market from 1977 to 1987 , except for 1980 and 1983. There was a decrease in total sales from 1987 to 1989. This coincides with the variation in stalls per season and number of different sellers per season, going up in most years and down in 1980, 1983, 1988, and 1989. The decrease in the number of sellers in 1988 and 1989 could be attributed partially to hail and other adverse weather conditions that reduced yields, shortened the growing season, lowered the quality ofproduce, and caused sweet corn to mature over a relatively

Table 1. General summary of farmers market activities for individual communities, 1977-89.

\begin{tabular}{|c|c|c|c|c|c|c|c|}
\hline Community & Population & $\begin{array}{c}\text { Date of } \\
\text { operation }\end{array}$ & No. years & $\begin{array}{l}\text { Avg market } \\
\text { days/season }\end{array}$ & $\begin{array}{c}\text { Avg no. } \\
\text { sellers/day }\end{array}$ & $\begin{array}{l}\text { Avg different } \\
\text { sellers/season }\end{array}$ & $\begin{array}{l}\text { Total reported } \\
\text { sales for best year (\$) }\end{array}$ \\
\hline \multicolumn{8}{|c|}{ Nonactive markets } \\
\hline Ainsworth & 2,256 & $1982-83$ & 2 & 16.0 & 5.0 & 18.0 & 2,500 \\
\hline Bassett & 1,009 & 1982 & 1 & 16.0 & 2.0 & 2.0 & NA \\
\hline Cozad & 4,453 & $1982-83$ & 2 & 12.5 & 3.3 & 4.5 & NA \\
\hline Grant & 1,270 & 1979 & 1 & 1.0 & 7.0 & 7.0 & NA \\
\hline Imperial & 1,941 & $1982-83$ & 2 & 8.0 & 3.5 & 13.5 & 650 \\
\hline McCook & 8,404 & 1980 & 1 & 12.0 & 3.0 & 10.0 & NA \\
\hline Ogallala & 5,638 & $1979-81$ & 3 & 7.3 & 5.0 & 14.7 & NA \\
\hline Average & & & 1.7 & 10.4 & 4.1 & 10.0 & \\
\hline \multicolumn{8}{|l|}{ Active markets } \\
\hline Benkelman & 1,235 & $1979-89$ & 11 & 10.9 & 5.2 & 16.3 & 3,700 \\
\hline Broken Bow & 3,979 & $1979-89$ & 11 & 11.6 & 3.5 & 8.0 & NA \\
\hline Curtis & 1,014 & $1979-89$ & 11 & 7.9 & 4.0 & 13.2 & 1,550 \\
\hline Gothenburg & 3,479 & $1980-89$ & 10 & 9.0 & 9.2 & 18.2 & 3,250 \\
\hline Lexington & 7,040 & $1980-89$ & 10 & 11.5 & 10.9 & 21.1 & 6,600 \\
\hline North Platte & 22,000 & 1977-89 & 13 & 19.8 & 15.9 & 62.0 & 38,024 \\
\hline Average & & & 11.0 & 11.8 & 8.1 & 23.1 & \\
\hline
\end{tabular}




\section{PRODUCTION AND MARKETING REPORT}

Table 2. Reported sales for the Nortb Platte farmers market from 1977 to 1989.

\begin{tabular}{|c|c|c|c|c|c|}
\hline Year & $\begin{array}{l}\text { Highest sales/season } \\
\text { per individual seller }(\$)\end{array}$ & $\begin{array}{l}\text { Highest sales/one } \\
\text { seller for one day (\$) }\end{array}$ & $\begin{array}{r}\text { Total yearly } \\
\text { sales }(\$)\end{array}$ & $\begin{array}{l}\text { Avg sales/seller } \\
\text { per stall per day }(\$)^{\mathbf{z}}\end{array}$ & $\begin{array}{r}\text { Avg sales/seller } \\
\text { per season (\$) }\end{array}$ \\
\hline 1977 & 590 & 170 & 5,500 & 34.59 & 96.49 \\
\hline 1978 & 1244 & 325 & 9,960 & 57.24 & 262.10 \\
\hline 1979 & 1210 & 300 & 13,050 & 55.77 & 197.72 \\
\hline 1980 & 1795 & 475 & 12,300 & 55.91 & 256.25 \\
\hline 1981 & 1760 & 308 & 15,240 & 56.03 & 311.02 \\
\hline 1982 & 2185 & 250 & 21,160 & 58.29 & 306.67 \\
\hline 1983 & NA & NA & 17,839 & 61.73 & 349.78 \\
\hline 1984 & 2700 & 160 & 23,061 & 75.86 & 480.44 \\
\hline 1985 & 4500 & 400 & 32,109 & 79.09 & 465.34 \\
\hline 1986 & 4700 & 517 & 35,294 & 80.03 & 425.23 \\
\hline 1987 & 4700 & 410 & 38,024 & 77.44 & 400.25 \\
\hline 1988 & 3363 & 410 & 29,128 & 71.22 & 383.26 \\
\hline 1989 & 3620 & 300 & 20,838 & 62.95 & 365.58 \\
\hline
\end{tabular}

Table 3. Seller participation in the Nortb Platte farmers' market from 1977 to 1989.

\begin{tabular}{|c|c|c|c|c|c|c|}
\hline Year & $\begin{array}{l}\text { No. market } \\
\text { days }\end{array}$ & $\begin{array}{c}\text { Avg no. sellers/ } \\
\text { day" }\end{array}$ & $\begin{array}{c}\text { Total stalls/ } \\
\text { season }\end{array}$ & $\begin{array}{c}\text { Different sellers/ } \\
\text { season }\end{array}$ & $\begin{array}{c}\text { Sellers returned from } \\
\text { previous year }(\%)\end{array}$ & $\begin{array}{l}\text { No. localities } \\
\text { representedy }\end{array}$ \\
\hline 1977 & 11 & 14.5 & 159 & 57 & -.. & 10 \\
\hline 1978 & 12 & 14.5 & 174 & 38 & 9.0 & 10 \\
\hline 1979 & 13 & 18.0 & 234 & 66 & 45.9 & 11 \\
\hline 1980 & 12 & 18.0 & 220 & 48 & 34.3 & 9 \\
\hline 1981 & 17 & 16.0 & 272 & 49 & 40.4 & 8 \\
\hline 1982 & 21 & 17.3 & 363 & 69 & 35.3 & 18 \\
\hline 1983 & 22 & 13.0 & 289 & 51 & 34.3 & 7 \\
\hline 1984 & 24 & 12.6 & 304 & 48 & 37.0 & 16 \\
\hline 1985 & 24 & 16.9 & 406 & 69 & 60.4 & 17 \\
\hline 1986 & 23 & 19.2 & 441 & 83 & 61.9 & 17 \\
\hline 1987 & 27 & 18.2 & 491 & 95 & 52.8 & 21 \\
\hline 1988 & 26 & 15.7 & 409 & 76 & 34.7 & 19 \\
\hline 1989 & 25 & 13.2 & 331 & 57 & 54.4 & 15 \\
\hline
\end{tabular}

One seller rents one stall per day.

'Based on bome address as listed by each seller.

short marketing period. Returning sellers from previous years add stability to market sales, but certainly cannot account for all the variation in year-toyear sales (Table 3). The increase in sales, beginning in 1981, was partly due to extra market days, resulting in more stalls being rented per season (Table 3).

The numbers ofsellers per market day, stalls per season, and different sellers per year vary from season to season and affect the total sales at a farmers' market. Total sales are closely related to the number of stalls rented per season, which, in turn, is related to seasonal growing conditions and number of market days.

The information collected in this 13-year study indicates that farmers' markets can be successful in rural communities. However, the success of the markets will vary from community to community and sales within markets will vary from year to year and from seller to seller. Farmers' markets should be considered for use as a marketing method for horticultural crops in smaller communities.

\section{Literature Cited}

Capstick, D. 1982. A study of direct marketing of farm produce in Arkansas. Div. of Agriculture, Univ. of Arkansas, Fayetteville, Agr. Expt. Sta. Bul. 861.

Courter, J.W., C.M. Sabote, and J.C.O. Nyankori. 1980. Methods of surveying direct market customers. HortScience 15(3):265-266.

Steinberg, S.L., JR. Novak, M.L. Vamosy, and B.D. McCraw. 1986. Fanning systems research applied to direct market vegetable production in Texas. HortScience 21(3):487-490. 